Research paper

\title{
From "living lab" to strategic action field: Bringing together energy, mobility, and Information Technology in Germany
}

\author{
Weert Canzler ${ }^{\mathrm{a}}$, Franziska Engels ${ }^{\mathrm{a}, \mathrm{b}}$, Jan-Christoph Rogge ${ }^{\mathrm{a}}$, Dagmar Simon ${ }^{\mathrm{a}}$, \\ Alexander Wentland ${ }^{\mathrm{a}, \mathrm{b}, *}$ \\ a WZB Berlin Social Science Center, Reichpietschufer 50, 10785 Berlin, Germany \\ ${ }^{\mathrm{b}}$ Munich Center for Technology in Society (MCTS) and TUM School of Management, Technical University of Munich, Arcisstr. 21, 80333 Munich, Germany
}

\section{A R T I C L E I N F O}

\section{Article history:}

Received 17 May 2016

Received in revised form 31 January 2017

Accepted 6 February 2017

Available online 21 February 2017

\section{Keywords:}

Energy transition

Electrification of transportation

Industry convergence

Strategic action fields

Living lab

\begin{abstract}
A B S T R A C T
Against the backdrop of the transformation of the German energy system, a new dynamic is emerging between the previously separate economic fields of renewable energy systems, transportation, and information and communication technologies (ICT). The trend towards digitalization and interconnectivity is prompting the formation of new corporate alliances and business ideas. We argue that the increasing interactions between actors in these sectors are evidence of the emergence of a new intersectoral field. Building on concepts from neoinstitutionalism, particularly, the framework of strategic action fields (SAF), we examine the overlaps and dynamics that are arising in an exemplar of what policy makers and planners often refer to as "living labs." With help of this case study we observe the cross-field innovation activities taking place at a particular local site. Our empirical examination draws upon a four-year-long ethnography of an innovation campus in Berlin, the German capital. This case reveals the development of interdependent interests and collaborations between both different industries and between companies and academic institutions. These interconnections are built, in part, by socially skilled actors, who act as border crossers between established fields.
\end{abstract}

(c) 2017 Elsevier Ltd. All rights reserved.

\section{Introduction}

Lately, one can observe the emergence of a diverse set of local innovation sites, which policy makers, planners, and engineers have dubbed "living laboratories" for research and development (R\&D) [1-3]. Social scientists, however, should not understand these often locally situated public-private-partnerships exclusively as spaces of experimentation, co-creation, and invention for future technologies. We argue that living labs also give momentum to the emergence of institutional formations between formerly separate industries, disciplines, and policy areas. In this paper, we aim to examine how these micro-level innovation activities contribute to the emergence of a new field. The field in focus comes out of three, in principle, distinct innovation areas: renewable energy systems, transportation, and information and communication technologies (ICT). We draw upon a large corpus of qualitative data collected over the time of four years at an urban innovation campus.

\footnotetext{
* Corresponding author at: Munich Center for Technology in Society (MCTS) and TUM School of Management, Technical University of Munich, Arcisstr. 21, 80333 Munich, Germany.

E-mail address: alexander.wentland@tum.de (A. Wentland).
}

We consider this self-declared living lab to be an example of a broader empirical phenomenon: the mushrooming of these kinds of public-private partnerships across the world, especially in Europe [4], where the transition towards a sustainable society has become a pivotal issue for policy makers. Setting up sites of experimentation as test beds for sociotechnical innovations appears to be a popular solution for achieving this goal [5]. A number of such collaborative initiatives are deliberately set up between established industries and disciplines in order to facilitate and foster intersectoral stimulation [6,7]. With regard to sustainability, the co-evolutionary transformation of both energy systems and transportation has stayed at the top of green growth and climate change mitigation agendas [8-11]. Social scientists have studied a variety of recent developments, in particular the state-driven attempts to transform national energy and transportation systems [12-14].

A profound transformation is currently underway in global energy supply systems. Since the ratification of the 2016 Paris climate treaty and even earlier, the majority of industrialized and emerging countries have striven to transform daily life and economic activity to achieve environmental goals. However, in many countries established structures prevail or co-exist with new alliances around low-carbon technologies. Governments throughout the world attempt to reconcile energy transitions with powerful 
incumbent industries, whose success is considered by policy makers to be synonymous with the viability of the overall national economy.

The urban innovation campus we have been studying represents a particularly enlightening setting for not only analyzing field emergence but also the German sociotechnical imaginaries related to sustainability with their manifold tensions [15]. On the one hand, both the German government and the German population see themselves as pioneers; after all, the government has abandoned nuclear energy and the country has a remarkably strong environmental movement by international standards [16]. On the other hand, many experts see Germany as dominated by incumbent industries. As an export-oriented economy with a high share of energy-intensive manufacturing businesses, Germany has found it difficult to implement the energy transition [17]. A similar problem seems to impede change among automobile manufacturers, who adhere to their still successful strategy, which hinges on exporting gasoline-demanding premium cars [18]. Added to this, Germany has an intertwined and hierarchical system of energy producers and users, which is already under pressure due to the volatility of renewable energy generation capacities and their uneven distribution [19].

In this paper, we focus on a particular kind of "sociotechnical niche" [20], an urban site of innovation designed to foster and promote the convergence between formerly separate industries. The campus is located in Berlin, the German capital, where the notion of an arguably game-changing Energiewende (energy transition) has dominated both the policy debates and the media discourse for years. We analyze the local dynamics, strategies, and negotiation processes at the campus based on expert interviews, participant observation and document analysis. In our opinion, this spatially confined niche provides an interface between renewable energy systems, transportation, and ICT - revealing both moments of convergence and of conflict. Due to the digitalization of electricity, transport, and communication, industrial actors with divergent product cycles, industrial logics, and innovation cultures are colliding in collaborative settings. Based on the guiding concept of what the actors refer to as "mobility-to-grid,"1; an institutional framework was constructed, thus allowing actors from different industries and academia to collaborate.

Conceptually, we integrate the theory of strategic action fields (SAF) $[21,22]$ with the approach of local innovation sites to capture the early processes of field emergence by looking at the particular actors' strategies and interactions in order to conceptualize these interactions on an organizational, rather than on a technological or discursive level. We argue that the increasingly dense interactions between three formerly disparate areas should be read as evidence for the emergence of a new intersectoral field.

This prompts a series of questions from an economic and technological perspective, which in turn allows us to draw some initial conclusions about the dynamics that are present when new fields are established or existing fields are restructured. Specifically, we would like to know: How does the local experimental context enable and shape the interaction between actors from largely separate economic sectors, namely renewable energy systems, transportation, and ICT? How do players in this emerging field view and evaluate this entanglement, especially their relationships with competitors and partners? What strategies do new and established companies from various industries utilize? Finally, can we identify

\footnotetext{
1 Whenever we refer to the intersectoral field between renewable energy systems, transportation, and ICT in the particular case of the urban innovation campus we examined, we will use the term "mobility-to-grid," which the involved actors use to demarcate their local niche and what we view as their strategic action field.
}

a common conception of an intersectoral field beyond the confines of the innovation campus, and if so, what does it look like?

\section{Strategic action fields and field emergence}

\subsection{Approaches to sociotechnical transitions}

In this article, we study the emergence of a new field caused by transitions in neighboring fields and the development of new strategic interests and collaborations between actors from these fields. In most current studies on energy transitions such dynamics have been framed in terms of sociotechnical niches $[23,24]$. The multi-level perspective (MLP) on technological transitions views such incubation spaces [25: 400], which are protected from economic competition, as a starting point for radical innovations $[26,20,27]$. From this perspective, technological transitions can only be understood by analyzing niches in close proximity to stabilized regimes. These stabilized regimes are defined as the dominant "rule-set of grammar" [28: 338], and are embedded in routines, technological artifacts and social networks, as well as macro-level sociotechnical landscapes, which consist of "technology-external factors" and "deep structural trends" [29: 1260]. These technologyexternal factors can include, inter alia, political decisions, economic development, environmental changes, and the like. In the study of transition processes, this threefold approach has become the most fruitful and widely used framework to study the emergence and change of sociotechnical arrangements. Our analysis connects to this body of literature insofar as we investigate societal, political, and economic developments in a - spatially defined - technological niche and relate such developments to larger institutional settings. We also build on the work on "multi-regime interactions" [30,31], which lays emphasis on the interrelated transformation dynamics on different levels on different sectors. In a similar vein, we are interested in the interactions and dynamics between at least three different sociotechnical domains: renewable energy systems, transportation, and ICT.

However, the MLP comes with certain caveats that limit its applicability for conducting an actor-centered analysis, which we propose for answering our research questions. A number of scholars have criticized the MLP for lacking a systematic and explicit "account for power, agency and general political economy phenomena" [32: 265]. Geels and others have addressed the issues of power and agency, among other criticisms, in their recent work [33-35]. However, most MLP-studies still focus on dynamics and interactions between relatively disembodied niches and regimes - not on socially skilled actors and their concrete actions. While this seems to be rather unproblematic when it comes to explaining longue durée transitions from one regime to another [12,36,30], it proves an obstacle for studying the emergence of new arenas of social action. We react to these conceptual shortcomings by applying the theory of SAF to capture the strategies of the actors involved in the creation of these new arenas, taking into account the current phenomenon of laboratory sites of innovation.

\subsection{From organizational fields to strategic action fields}

When approaching intersectoral dynamics in terms of actors, strategies and agency, the first question that needs to be addressed is how to conceptualize a pre-commercial niche. Scholars in organization studies have examined domains of institutionally connected actors as "organizational fields" [37-39]. DiMaggio and Powell define organizational fields as "sets of organizations that, in the aggregate, constitute an area of institutional life" [37: 148]. These networks of organizations are reproduced and stabilized by common "meaning systems" [40: 57-59]. Such systems of meaning 
constitute the boundaries of an organizational field, within which appropriate behaviors, affiliations, and relationships between different organizational communities are defined [41: 165].

In recent years, relevant conceptual debates have increasingly revolved around the possibilities for structural change, as observed in the energy transition field, and the configuration of new field-like organization networks [42-44]. Hinings et al. have defined change as the transition from one inscribed and legitimized pattern of practices to another [43: 304], arguing that organizational fields are based on compliance with implicit ("taken-for-granted") rules and standards. In a pre-commercial niche, however, at least some of the institutional elements have not yet been developed. When studying emerging fields, such fields should therefore not be identified based on tangible manifestations of organized coalitions but rather based on the increasing informational exchange and interaction density between previously disparate organizations and actors. Hoffman [45: 352] suggests three indicators, which we use as the basis for our empirical analysis: (1) "the extent to which certain organizations interact" (2) "an increase in the information load which they share" and (3) "the development of a mutual awareness that they are involved in a common debate." As our empirical research will reveal, within the period of investigation the campus experienced a strong increase and intensification of activities, including setting up cross-sectoral collaborations in research and business.

In our study, we further bring into focus the strategic interests of the actors and the tensions immanent in an emerging technological field. This perspective has been promoted in recent years by U.S. economic sociologists Fligstein and McAdam [21,22] in their theory of strategic action fields. SAFs are meso-level social orders that are typically characterized by the antagonism between incumbents who possess a privileged position in the field and challengers who "recognize the nature of the field" but "usually articulate an alternative vision of the field and their position in it" [45: 11]. The fields cannot be clearly distinguished from one other, nor do they exist independently of the perceptions and definitions of the actors that are considered part of them. Fligstein and McAdam use the metaphor of the matryoshka - nested Russian wooden dolls - to illustrate that each SAF is ultimately composed of other, smaller SAFs that relate to each other in very different and often hierarchical ways [22: 58].

In their programmatic essay, Fligstein and McAdam differentiate between three field states: (1) "unorganized or emerging" (2) "organized and stable but changing" and (3) "organized and unstable and open to transformation" [21: 11]. They define emergent i.e. not yet stabilized and hence relatively anarchic - SAFs as an "arena occupied by two or more actors whose actions are oriented to each other, but where agreement over the basic conditions of the SAF has yet to emerge" $[21,22]$. These frames may hence act as a "social space where rules do not yet exist, but where actors, by virtue of emerging, dependent interests, are being forced increasingly to take one another into account in their action" [21,22]. In the case study analysis in Sections 4 and 5 we empirically investigate whether or not the orienting and reference towards one another actually "takes place" at the innovation campus, and how actors perceive this development.

A prominent factor of our investigation are skilled social actors who are considered central to the emergence of a new field, since they create arenas for exchange and cooperation between different social groups, perform translation work, and produce new cultural "frames" for a field [21:7-8]. In our empirical account, we illustrate how these skilled social actors, who are border crossers travelling in different cultural and institutional worlds, constitute and shape an emerging intersectoral field. To change institutional structures permanently, actors must act as "institutional entrepreneurs" [46]. This is particularly successful when the central actors in the process identify opportunities that have perhaps emerged from processes of change and upheaval within established fields, "to align one's account with the dominant orders of worth in the field, thereby convincing powerful actors to accept one's account as convention" [47: 1089].

\subsection{Integrating the laboratory setting into the theory of strategic action fields}

One of the places where policy makers, entrepreneurs and researchers facilitate and encourage this kind of border crossing is pilot projects and public-private-partnerships in which sustainable technologies are developed, tested and demonstrated. Recently, a host of such test beds and "real-world experiments" [48] have popped up in various innovation fields. Such experiments are persistent, open-ended irritations of existing markets, actor constellations and industrial cultures. Gross [49: 614] points towards the unique features of real-world experiments that distinguish them from the kind of experimentation taking place in conventional laboratories. Government-sponsored testing sites could be seen as "a special (micro) case of the corresponding large-scale experiment happening in society." So called "bounded socio-technical experiments" (BSTE) "attempt to introduce a new technology, service, or a social arrangement on a small scale ... carried out by a coalition of diverse actors and (are) driven by longterm and large-scale visions of advancing society's sustainability agenda" [50: 191].

However, little attention in research is given to the importance of concrete localities where these innovation activities happen and knowledge is produced and distributed [51]. Especially due to the increasing decentralization of energy supply systems, the role and impact of local innovation settings are on the rise. As experiments of any kind take place in a certain locale, the search for novel formations often starts here. These protected spaces constitute niches in an otherwise highly structured system [52]. Such analyses regard these sites neither as laboratories in the traditional sense nor as sites of mere political justification for large-scale public investments. To them, such places can be seen as "urban laboratories" [4] or "living laboratories" [3] that seek "to transform a part of the city into a laboratory by saturating it with monitors and sensors, relay stations and social engagement processes" [53: 6]. ${ }^{2}$ Such experimental niches stay away from market pressures, since actors usually set them up to provide a proof of concept before scaling up.

We argue that the material locations where sociotechnical reconfigurations take place also play a crucial role in the formation of a new field. They not only prompt the creation of new knowledge and practices; they also lend them authority and universality [54-56]. For instance, laboratories for research and development are not only authoritative centers of legitimate knowledge, they can also act as venues for events and encounters that can bring new fields to life. Conferences, fairs, competitions, workshops, discussion forums and presentations of prototypes can be understood as "field-configuring events" [57]. At the innovation campus under investigation, they take place frequently and constitute an important business factor for the campus management, on the one hand, and enable companies located at the site to set up their own events, on the other. At such "early stage events," people from different contexts come together for a limited period of time to consciously and purposefully lay the foundations for a new field [58]. For this

\footnotetext{
2 A living laboratory is, compared to the artificially controlled environment of a traditional science laboratory, more "messy"; its legitimacy is not derived from exact reproducibility but from the collection of data "on almost every aspect of the experiment with sufficient accuracy to identify patterns and make robust causal inferences" [53: 5-6].
} 
reason, it makes sense to take a look at the local dynamics and strategies of the actors present at a single location.

In this section, we have outlined our conceptual understanding of the campus as the formation site of an intersectoral SAF between the fields of renewable energy systems, transportation, and ICT. At this site, one can observe processes of convergence and information exchange as if they were under a "magnifying glass." Although our investigation is limited to a single case study, and we therefore cannot generalize our findings to the development of entire industries, our observations of this specific site still reveal in-depth empirical material, as we will show in the following. To do so, we will emphasize three factors for the emergence of a new field and which guide our empirical investigation: 1 . global conditions and local platform testing; 2 . perceived interdependent interests; 3 . socially skilled actors as border crossers.

\section{Methods}

Recognizing the plurality and diversity of existing demonstration projects, we have selected this empirical case study to underpin our research with in-depth qualitative empirical data [59]. We draw on this distinct case because we see the campus as a representative of the larger test bed phenomenon that has proliferated in many different places in the energy transition context lately, as we mentioned in the introduction. The innovation campus has hosted among others two distinct research projects ${ }^{3}$ in which we were engaged as project partners. One took place from mid-2013 through mid-2016, the other started in March 2013 and is still running. Being part of the collaborative projects and also being located on site enabled us to gather a wealth of empirical data covering the period in total from 2013 until 2016.

This paper builds on three major data sources: First, being in charge of participatory observations in the research projects enabled us to participate in project meetings on a regular basis, in events like group workshops as well as to have smaller, also informal talks with project members. Consequently, we were granted the chance to collect different kinds of empirical material over a four-year period. Considering the fact that the actors' motivations, internal power relations and collaboration experiences cannot be studied from "the outside," our methodological approach of what we call "field embedded research" offers unique and valuable data for understanding the mechanisms and functions of innovation sites practically "in the making." This approach pays respect to the fact that the potentially disruptive nature of technical and organizational innovations in the empirical field requires a new understanding of participatory research. It brings the researcher at least temporarily - into a "frontier position" within the respective field, which demands a heightened awareness of this position and additional methodological rigor [60]. Overall, this strategy to access the field proved especially useful for mapping and understanding the local innovation dynamics, negotiation processes and interactional practices in collaborative initiatives.

A second source of data comes from 49 interviews with the relevant actors at the campus that derive from the two research projects that back our analysis: Out of these 49 interviews, 19 were carried out within the project "D3 Micro Smart Grid EUREF” between 2014 and mid-2015 as semi-structured, narrative-generating interviews $[61,62]$. We selected our interviewees from a list of about 70 companies and research facilities located on site (as of 2015) to cover the range of different branches, of different organizational sizes, and to include long-term tenants as well as newcomers. The interviewees included senior scientists, managers, and management personnel

\footnotetext{
${ }^{3}$ For further information on the research projects please see the acknowledg-
} ments. who are responsible for strategic decisions within companies in the renewable energy systems, transportation, and ICT sectors, including both new start-ups and established market actors. The other 30 interviews were conducted as part of the research project "Research campus Mobility2Grid" with key actors in the different thematic fields of the project. The interviews were conducted from 2013 to 2015 and designed as a two-point longitudinal study. But as responsibilities and personnel shifted and changed to a large extent in the initial stages of the project, only ten out of 14 interviews from the first phase could be interviewed again in the second phase. Therefore, six new project members were interviewed in the second phase. ${ }^{4}$

And finally, we collected and analyzed documents covering press releases and further communication materials, websites, project proposals, and presentations from various meetings. Among others, fruitful sources of data included minutes and reports documenting the project progress, which we analyzed focusing on explanations and reasons for deficits and delays indicating collaboration obstacles.

Our analysis of these different types of data was informed by content analysis and a grounded theory approach [63,64]. Using a combination of deductive and inductive methods, a first set of codes was derived from our interest areas and the theoretical background. Throughout the coding process, the code list was expanded continuously and iteratively based on the empirical data [65]. We coded for the actors' motives and interests in being part of the campus community (expectations and experiences), collaborations and interactions on the site (including conflicts and challenges), their perceptions of the technology and technological development (technological outcomes and obstacles), and their perspectives on the respective field of research and current challenges. Data organization and categorization were supported by using Maxqda software. Since all available documents and the interviews transcriptions are in German, the quotations added in this article have been translated into English.

\section{Introduction to the case study}

With the aim of fostering the creation of a "smart city district of the future," an area of Berlin has been developed as a business and research site to further the energy transition since 2006. An investor purchased the area of a former gas storage facility in 2007. The site contains a historic gasometer that defines the site's external appearance along with some redbrick buildings that are preserved as sites of historic interest. The preservation of existing buildings and the conversion of the former industrial site was driven by the vision of creating a platform for all questions regarding energy. Several new buildings have been built in recent years. Plans are afoot to power the entire location with wind turbines, solar photovoltaic systems and biogas-powered cogeneration units to ensure that it is mostly $\mathrm{CO}_{2}$ neutral. A scalable micro smart grid - a decentralized, intelligent power grid - is projected to connect individual renewable energy sources to each other using ICT [66].

\footnotetext{
${ }^{4}$ In this article, we only took quotations from nine interviews, which exemplify statements backing our analysis, yet the full set of 49 interviews informed our study. The goal of the interviews was to generate knowledge in the following interest areas: first, the motivation to settle down at the innovation campus; second, their actual assessment of what they found, how far their initial interests and expectations were met; third, their perceptions of the cooperation experience in joint projects; and finally, their stakes in the projects and their assessment regarding the development of the technology in general. A more detailed description of the interviews quoted in this paper is presented in the list of interviewees in the acknowledgements, including each interviewee's function and the date when the interview was carried out The duration of the interviews varied approximately between $45 \mathrm{~min}$ and two hours. All interviews were digitally recorded and transcribed.
} 
The campus is a place of work and demonstration as well as a laboratory and a research subject for various private and publically funded projects. Here, science and industry work cooperatively in the thematic cluster of renewable energy systems, transportation, and ICT. In recent years, numerous start-ups, small- and medium-sized enterprises, research institutions and branches of larger German but also international companies have opened facilities at the site. Moreover, the site also hosts an incubator to promote start-ups with sustainable business concepts. In total (as of the end of 2016) more than 100 companies and research facilities with nearly 2000 employees are located on the campus. Within the time period covered by our empirical research, the campus experienced a growth phase that was characterized by extensive expansion in terms of construction activities, settlements of new tenants, and the start of different research projects and collaborative initiatives [67].

All in all, we observed a densification of activities that led to an increase, first, of interaction between organizations and, second, in the information load which they share, according to Hoffman's analytical indicators [45: 352] as presented in Chapter 2.2. In most cases, the organizations are loosely connected due to their involvement in the thematic clusters mentioned above. In addition, they are also linked directly through their joint work in various, mostly publically funded, projects. Despite divergent expectations about the development of the field, the theme "mobility-to-grid" functions as a guiding vision on the campus and within the different projects. It serves as a point of intersection or bridge between the present and future by unleashing a normative power to nurture the site's development process [68].

\section{The emergence of mobility-to-grid}

\subsection{Global conditions and local testing platform}

Before we turn our focus towards the campus dynamics we aim to emphasize that the emerging intersectoral mobility-to-grid SAF should be seen in the context of global developments in environmental policy. It is important to understand the actors' strategies and the origin of the innovation campus against the backdrop of particular contextual conditions that work in both ways. They foster competition and increase pressure for companies to innovate. At the same time, they create increasingly favorable conditions for intersectoral activities since they open up room for maneuver and give new impetus for innovative products and business models.

The trend towards decarbonization and sustainability across all areas of consumption and production creates favorable conditions for linking the formerly separated fields of renewable energy systems and transportation. Climate scientists unanimously agree that in order to curb the greenhouse effect and the associated changes in the climate, we need to dramatically reduce carbon dioxide $\left(\mathrm{CO}_{2}\right)$ emissions, amounting to an almost complete decarbonization by 2050 [11]. Achieving this goal implies reinventing the main pillars of all economies: energy, production, and transport. The transport sector presents one of the greatest challenges to decarbonization. As it stands, the transport sector in the OECD countries is responsible for over a quarter of their current $\mathrm{CO}_{2}$-emissions [69]. According to some engineers, electric vehicles could potentially fill this gap, a notion that is supported by some early simulations and pilot projects [70], creating another link between the two fields. There have been initial tests with various technologies and usage scenarios, and the integration of electric vehicles as productive elements in a future "smart grid" is being tested in federally funded showcase projects on electric mobility [71] such as the one in focus.

In Germany, electric mobility is now explicitly framed as a necessary component, as a "key" to the energy transition. The latest report from the National Platform for Electric Mobility (NPE), an association of leading representatives from politics, business and science, has emphasized this synergy potential:

Worldwide, electric mobility is a key to a climate-friendly transformation of mobility, and in Germany it is a part of the energy transition... In the future, electric vehicles will be able to use their energy storage capacity to compensate for the fluctuations in wind and solar power (smart grid), thus supporting the development and market integration of these volatile sources of energy.

[72: 3,own translation]

The benefits that electric vehicles could offer in the switch to renewable energy sources range from the short-term stabilization of distribution networks to the comprehensive provision of storage capacities to enable individual "vehicle-to-home" solutions [73]. In this context, companies and city planners have been discussing service-based "on demand" and "sharing" business models. However, this is based on a fundamental shift from the car as a private vehicle to a product that is offered by a professional provider as part of a service. The consequences of this change for vehicle manufacturers and the transport industry as a whole would be significant. The demand for cars to meet mobility needs could decrease, but at the same time additional services would have to be offered in order to integrate the various modes of transport and interconnect them with the power grid [74].

The envisaged usage scenarios and business models presume that these will largely be made possible through the use of advanced ICT. The development of market-ready ICT within mobility-to-grid projects is therefore essential for the emergence of the intersectoral field. They ought to make it easier for the users to access transport services in general and facilitate an easy connection between different forms of transport. ${ }^{5}$ Smartphones can play a key role here: they not only deliver the necessary real-time information but also serve as a ticket, access key, and personal assistant in all transport situations and as a charging remote control. ICT - which operates in the background and without being noticed by the user - facilitates the integration of different modes of transport and the linking of transport and electricity suppliers. This enables network operators and electricity suppliers to develop smart home and smart grid models $[75,76]$. The coupling and integration of the previously separate electricity and transport sectors will only be possible if smart grids can synchronize complex data.

We want to emphasize here that information and communications technologies possess their own catalytic function for the merging of historically separate sectors. They do so by making it possible to radically reduce the interaction costs of cross-sectoral cooperation and by providing user interfaces that are simple, yet flexible. Digital media primarily act as access technologies for users, and in the background, they act as bridges between the different operators. They thus have the potential, via compatible nexuses, to act as a common technical docking position for representatives of the two sectors - both the electricity and the transport sector - and may hence play a key role in the emergence of a new SAF. This is particularly evident in local mobility-to-grid pilot projects, as the following quotation shows:

And at the end of the day there is the question:, Are there any automotive or energy people at all doing business there? Because at the end of the day the core skills are always networking services in the

\footnotetext{
5 About $90 \%$ of people under 30 years of age already have a web-enabled smartphone. The fact that all the transport services and their various vehicles are recorded digitally means they are always recognisable and usable. The individual vehicle plays an increasingly less important role: This means that technical specifications are not crucially important; the choice is usually made based on pragmatic criteria, i.e. the user chooses the vehicle that best suits his or her needs [83: 7-18].
} 
IT field. Who has those? This quickly brings us back to Google or Apple or IBM, companies who come from this area ... and often it is also the little guys who use this innovative strength, this selfsufficiency to pull ahead of many others. This is open, this is very, very open, but it remains exciting." (I2)

More recently companies from the ICT sector have been increasingly active in mobility-to-grid projects and have become more important on the examined innovation campus. As Fligstein and McAdam [22: 69] have already pointed out, these actors' innovative power has a great influence on both existing and newly emerging fields: "The innovations emanating from various stakeholders (transform) the existing order and their own position in an imperceptible way."

Innovation processes always happen in specific places. Therefore, we turn the focus to the micro-level analysis of the strategies that the actors involved in this process use to stake their claim in the emerging field. We argue that the local spaces of engagement are sites where "specific pasts and presents get connected as well as where global and local temporalities need to find arrangements" [77: 194-95]. Although, global goals like decarbonization, electrification and sustainability provide increasingly favorable conditions, as we have shown in the beginning of this section, there exist neither a defined market nor viable business models for most of the technical solutions and concepts developed by on-site actors to integrate electric vehicles into smart grids. The technologies have not yet reached the market maturity stage. Although our interviewees have expressed their hope for future applicability, overall they perceive it as an "uncultivated field" for which viable business ideas have yet to be developed:

"But the issue of smart grids is just still so uncultivated, this field that one may still get involved in designing them, in contrast to other areas, where, due to the market situation with the few companies that exist, there is relatively limited leeway." (I3)

Therefore, we consider the new field as an open space for action, which offers opportunities to bring sectors together but at the same time remains a space where interests collide and organizational decisions have to be made.

\subsection{Perceived interdependent interests}

In the following section, we elaborate on this tension by shedding light on the different actors' interests towards this, what we call, open space for action and their motivations for being part of the particular living lab, respectively in how far they subscribe to the guiding "mobility-to-grid" vision of the campus. On the one hand, it allows actors from previously separate sectors to participate in developing the new field, although they do not share ideas about its core. On the other hand, the actors have divergent expectations and pursue different strategies, which they deploy to influence the direction and development of the field. Following Hoffman [45: 352], our empirical observations show that the interactions between the actors are becoming increasingly dense and that the awareness of participating in a joint debate is prevalent. The representatives of the various sectors on campus exchange information in both formal and informal ways. They cooperate within joint research projects and react to one another: "they want to be there when innovation is happening, perhaps even get to know and understand innovations" (I4), said one interviewee when explaining the engagement of major corporations in the projects.

At the same time, they are competing for interpretative power and for the limited resources in the new arena. The actors from each of the sectors are proceeding from very different expectations and assumptions about the field's future, which are strongly influenced by their individual core competencies. To gain this power, they try to steer the meaning of the field's development either in one direction - "that this overarching consideration on the part of energy providers is actually the decisive one" (I3) - or in the other direction - "that the vehicles are indeed a more important storage medium to test the whole thing" (I5). Taking heterogeneity into account, experimentation as it happens in living lab settings such as the innovation campus entails negotiation of diverse expectations of possible futures, as well as the "remaking of social relations across chains of actors involved in or influenced by transitions in socio-technical regimes" [5: 5].

In some cases, the actors' apparent openness is revealed to be a strategy of patient observation of the developments that occur in the process of field emergence. The actors register that something new is happening in this area and want to participate in it, without being the drivers themselves. Here a difference between the sectors can be observed. While digitalization and actors within the ICT field act as a catalyst for the emergence of the mobility-togrid field, the traditional incumbents in the energy and mobility sector have adopted a "wait and see" approach, with the exception of some smaller innovation projects. At the same time, given the eroding business models in the automotive and energy industries, as well as the investment and expectation uncertainties these sectors currently face, there is a need to undertake massive reorganization in these very areas. The principal drivers of such shifts are proactive changes of corporate focus rather than political decisions, as described in the previous section:

"That determines our complete corporate focus, just as it does for all other energy companies, because the business models only partially work the way they did 20 years ago, and need to be completely changed. So it has extremely serious implications because the energy market is completely changing, and we have to adapt as well." (I6)

For the constellation of actors in the mobility-to-grid field, the two-faced character of their openness to further development becomes apparent in the tension between cooperation and competition. Since there are no individual actors that can systematically provide complete solutions to integrate electric vehicles into smart grids, further technological developments depend on the cooperation between heterogeneous actors.

"They say I want energy here and now, I want heat, and I also want cars, and I want it all to be regenerative. At the moment, no one can provide this. One party only ever has this, and so, and the site should be a type of exercise, and as is always the case, because there's no one who can do it, we'll do it ourselves." (I1)

We argue that in this early stage of technology development, the cooperation is ascribed such great importance due to the emergence of the new SAF marking the beginnings of an intersectoral convergence of the energy and mobility fields. While the electric mobility SAF or the technological niche described by Bakker et al. [23] as the "car of the future" represent new subunits within established fields or market areas, the mobility-to-grid SAF emerges between several previously separated fields. In the current phase of field emergence, interaction between actors with different, fieldspecific types of knowledge appears to be a necessary condition. In this process, individual new technologies - considered to be "basic innovations" - could serve as a starting point for developing complementary interests, as the following quote shows:

“... and then others come and say, okay, now maybe you can connect the lamp there and control it with that thing. Then the next person comes and says, I have a kind of parking sensor in development here that we can attach on the top there right away. ... Things like this come together and you say, hey, great, now different things are growing together." (I4) 
Competition was a theme that repeatedly arose in the interviews, especially when direct competitors are participating in the same or similar projects. This can be illustrated by the example of the establishment of a collective rights company. The founding of the new company was a necessary condition for receiving public funds. In this instance, although there are currently no specific business models, expectations of the future recoverability of cooperation income makes competition a topical issue. The result was that one of the project partners backed out of the contract shortly before the company was founded.

Our interviews also revealed a latent fear among the "smaller" partners of "being sitting ducks" (I4) and of being "blown away" by larger companies, as one interviewee from a start-up reported:

"We are small. ... So you can just blow us away in a short period of time with decent money and decent resources. And as a founder you have enormous respect for that. Because we live from innovation and speed and certainly not from the fact that we can do things with large, deep pockets behind the backs of people who really want to do that." (I4)

Some of the smaller businesses and start-ups on the campus have the integration of renewable energy systems, transportation, and ICT at the very core of their business models. Thus, they act as accelerators for the emergence of the new field. Their participation in joint projects on the campus provides them an opportunity to cooperate with other businesses and attract investments. Yet, it also harbors the danger that they get forced out of the market if the larger companies pick up their ideas.

The diverging interests in terms of business prospects points to the deep-seated tension between smaller and larger companies referring to size, power, and resources. In many of the interviews, the actors touched upon the time-related challenges that are inherent factors in innovation processes. To the some companies, the innovation campus bears the risk that competitors can become aware of the latest developments merely due to proximity. These firms are willing to take this risk for the benefits that comes with the proximity: A spatially defined area may support the coordination and synchronization of time-shifted innovation cycles, e.g. by participating in joint $R \& D$ projects that are conducted on the site.

Hence, the campus reveals the tension between cooperation and competition an experimental niche entails. Fligstein and McAdam consider reaching a common understanding of the boundaries and rules of the field an essential characteristic of a SAF. As we observed in our four-year-period of participant observation, this often seemed difficult to achieve, because of the ambiguity the actors experienced in their shifting roles, seeing other companies, in some instances, as collaborators and, in other instances, as competitors. The analysis of our interview material indicates that developing a more stable understanding of their relationships is a prerequisite for the actors to consider themselves part of an emerging field. Therefore, at this early stage of field development, the social construction of a field does not take place based on a common view of the field; instead, a preliminary consolidation takes place based on the repeated interactions between the heterogeneous actors across boundaries that would not have taken place otherwise.

\subsection{Socially skilled actors as border crossers and interfaces}

In addition to the development of interdependent interests and an intensification of interactions, we find another type of enablers for the emergence of a new field in our data: We call them "border crossers." Borders as fundamental orientations of a social and symbolic order do not represent stabilized and permanent solutions but are, instead, constantly redrawn through processes of stabilization and destabilization. With regard to the management of borders, "border crossers" are needed, actors who know and understand the requirements of different social worlds [78,79]. These socially skilled actors help facilitating cooperation by providing meaning to others, helping them to "attain ends" [80: 113]. They are socially skilled in the sense that they are "better at attaining cooperation than others" [80], because they can make sense of particular situations and produce shared meanings. We understand border-crossers to be actors who are not attributable to the traditional fields of renewable energy systems, transportation, and ICT but who move simultaneously within several sectors and act as intermediaries between them. When a new SAF emerges, border crossers play a pivotal role by doing a kind of translation work and bringing together actors from different fields. In this sense, border crossers are very similar to the socially skilled actors introduced by Fligstein and McAdam; however, their special quality is that they assume an important interface function between existing SAFs.

Border crossers can be individuals, organizations and companies, or networks. We conceive of these actors as a specific type of institutional entrepreneur [46]. We argue that these actors are needed to mediate between the perceptions and logics of stakeholders' different orientations. They speak the stakeholders' different languages, are familiar with their different reputation systems, and look for ways to align competing goals. The skill of getting others to cooperate by focusing on "evolving collective ends" [80: $16]$ is a crucial feature when we take the actors' diversity into account. On the campus, border crossers derive their particular importance for cross-field cooperation processes from the heterogeneity of the actors, who present diverging individual structures, work with different reference systems and have varying organizational structures and production cycles:

"There are three sectors that are in there, which plan quite differently, which are aligned differently, which differ in the way they think, in their time scales and this is the major challenge. . Energy economists often plan in decades, and even now that is still fixed in their heads." (I2)

To emphasize the role of border crossers for the emergence of an intersectoral field, it is necessary to highlight the particular characteristics of the involved sectors that impede integration. Aligning the periods and speeds in which different sectors plan and operate are essential for the development of intersectoral innovations. Yet, the renewable energy, transportation, and ICT sectors differ significantly in their respective innovation cycles. With the energy transition and the goal of an energy architecture organized in a decentralized manner, the energy companies face a decline in planning and investment security, which is currently supported by a centralized structure. The industry perceives itself as facing a new kind of innovation and pressure to change because renewable energies have become more relevant and substituted fossil fired power plants more and more. At the same time, new flexible players have come up to challenge the established energy market [81]. In contrast to this, the automotive industry has traditionally been more driven by (incremental) innovation, not least because it has to constantly assert its position on the international market. Nonetheless with production times of a few years, the innovation cycle of a new vehicle is still comparatively long compared to the speed at which the ICT industry puts out a new generation of smartphones.

Border crossers have the ability to bring together various actors from these different sectors. In fact, many of our interviewees involved in collaborative projects located on the campus report that such border crossers made the initial contact with the other partners and were the reason for their entry into the new field.

"I don't know how the project or the idea came to be; I only know that we were approached by our partners at [border crossing organization]. . 'There's something in this, have a look it."' (I9) 
The joint projects provide opportunities for companies, research institutions and other social actors from different sectors to connect, and constitute an arena of exchange. In most cases, the projects are funded by the regional and/or national government as part of their efforts to realize the energy transition and promote sustainability. In accordance with the objective to bring together actors from different sectors and disciplines, the funding guidelines of the projects require transdisciplinary cooperation. If stabilization occurs (e.g. by research results, successful business models), these projects could become the nucleus for the emergence of a new field.

"And it makes sense for such projects like [project name] to prepare a chart on which each partner identifies its action area. ... And so far the projects we've established here are really always so versatile that you can expand them in every direction" (I1).

In contrast, for the companies coming from the adjacent fields, engaging in these projects does not mean fundamentally changing the company's strategy but instead offers the opportunity to tap into new business areas.

"For example, electric mobility was an issue that started on a small scale, where we had to learn through the projects how a charging station works, where do you get them. ... And from that a business can develop. Today we have products related to charging infrastructure that we distribute throughout Europe." (I4)

Hurdles for cooperation not only derive from sectoral differences but also but also from different organizational structures, e.g. when we look at international corporations and start-ups in our case. Unlike start-ups, which often occupy niches in between established players, corporations use intersectoral project networks as trial runs for the future expansion of their businesses into new fields, without having to leave their existing field.

"As a solution provider for energy management and all that, the result is of course that we can contribute a lot of hardware here... So that's how we got into the whole thing, through our core competencies." (I3)

In keeping with this, those working in intersectoral technology development projects are often not located in the core areas of the corporations but in separate innovation departments. These units and individuals often have an unclear status within the company, which expresses the inherent tension between the core business and the development of new areas of activity.

"Because I am in such a special situation, in a solitary position within the company, because I'm the only one specifically dealing with the issues of the energy transition and I'm busy with only that, maybe that's why I have a different point of view from the majority of employees." (I7)

The necessary trial-and-error process and the short- to mediumterm orientations in the development of business fields run contrary to the long-term logics of some company structures, which executives from other industries consider lethargic. In these cases, laboratory settings can provide space for testing and engaging on a small scale and in a rather short period of time. From our data we also learn that it is highly beneficial that the border crossers are also located on the campus and that they have been part of it from the constitutional phase onwards. They have been engaged in the site's development and have participated in a substantive way in the creation of a guiding vision. An organization's engagement in setting up demonstration projects is often based on mere assumptions and expectations towards future developments, which function as "narrative infrastructures" [14: 1361] to bridge the present and the future status, e.g. by conducting pioneering projects. The concept of test fields and experimental settings is even based on the exis- tence and production of expectations; the basic idea and character of living labs is to show and demonstrate something new that has not yet proven to work on a large societal scale. One company representative expresses the hope to use the urban context "as a test or implementation environment for many of these technologies and subjects ... at least in the way we present it externally, perhaps not carry it out quite so" (I8).

Regardless of their position in other areas of activity, when companies are acting in arenas from which new fields can emerge, they first have to find their place. Large corporations that act in several thematically related business fields are particularly well placed to participate in the emergence of a new field, either with several divisions simultaneously or with different divisions over time. One company in our sample illustrates these "search and restructuring processes" [82: 265] very effectively: Initially, its research activities on campus related to the charging station business, but it dropped this focus over time and adopted a new focus that involved building a mobility platform and the electrification of buses.

Taking these findings seriously, we argue that studies of SAFs should give greater consideration to the internal structure and focus of a company when observing the emergence of new fields. If cross-sectoral projects are understood as test runs for the emergence of new SAFs, depicting the stakeholders as closed entities is insufficient. In this respect, the schematic juxtaposition of challengers and incumbents is simplistic. In some areas, an opposition of this kind may well be a valid description. ${ }^{6}$ However, in order to describe the emergence of a new field, a dichotomous perspective of this kind does not suffice but needs to trace socially skilled actors who are more mobile than others, which allows them to cross boundaries between sectors or within a company and to induce cooperation. After all, we should not forget that companies are simultaneously active through their various divisions and departments in several, mostly interconnected or neighboring business fields. They may occupy different positions in the hierarchy of each of these fields - but, from an actor-centered perspective, this diversification of the portfolio is an action strategy aimed at mutual observation and participation.

\section{Conclusion}

In this article, we have looked at signs pointing to the emergence of a new field at the intersection of the three fields of renewable energy systems, transportation, and ICT. We did so by analyzing the local context of an urban innovation campus. Although electric mobility has not yet been a resounding success in Germany and the transition to an energy system based on renewable resources remains a highly competitive terrain, our research indicates that interdependent interests between actors from different sectors are evolving due to increasingly favorable context conditions for intersectoral activities. Employing Fligstein and McAdam's strategic action fields approach and reflections on the analysis of processes of field emergence [45], we have suggested that a new SAF is forming, in which companies and research institutions increasingly refer to one other across the boundaries of their traditional sectors. Practices of collective understanding and heterogeneous collaboration are developing - even if they are still timid and subject to failure. Against this background, we summarize the results and reflect upon the policy implications of these findings:

\footnotetext{
6 In the field of autonomous driving, for example, Google recently challenged established automakers with its ambitious development projects. Based on the conflict over the municipalization of the Berlin energy network, Blanchet [84] has been able to demonstrate the power struggles between two local initiatives and the coalition of the establishment represented by the Berlin Senate and the energy group Vattenfall.
} 
Global conditions and local testing platform: At the local level, a number of actors has conceived a living lab coming out of a public-private partnership, or state-supported project alliance, which these companies and academic institutions want to become the nucleus of a new intersectoral field. This site provides a platform for heterogeneous cooperation at a specific location. The living lab setting institutionalizes an arena of exchange and experimentation that allows the actors involved to "move into the unknown" and to use the "unavoidable failures or mishaps as a basis for learning" [49: 618] without immediately facing market pressure. Intense communication and joint events between partners from different sectors and disciplines help create an atmosphere of innovation and co-operation, even though, this does not happen automatically.

Perceived interdependent interests: The ultimate direction of the intersectoral field will depend on which actors prevail and what order and rules the field will have. Whether a hierarchy or a coalition will emerge depends, among other things, on how resources including power, knowledge, and money are distributed. However, both a hierarchy and a coalition would imply a stabilization of the field. Until this occurs, a situation of instability, disorganization and conflict may well arise, which could also last for a longer period of time [22: 75]. In this context of uncertainty, new and established actors are currently observing and converging with each other, as we have shown.

The emerging intersectoral field marked by the umbrella term of "mobility-to-grid" is characterized by a tension between cooperation and competition and presents itself to the actors as an open space for action, the development of which they try to influence with different strategies. Depending on their industry, the actors bring diverse ideas to the technological development process and try to influence the development of the field accordingly.

Thus, the living lab not only allows for experimentation and data collection on various aspects of the connection between mobility and energy by using ICT but also sets the stage for the competition between differing frames and views of the field. The development of interdependent interests is a necessary condition for the emergence of a new SAF, but this interdependence does not bring about a shared understanding.

Socially skilled actors as border crossers: The initiators of such projects are often socially skillful players whom we call border crossers, because they operate between different sectors and act as intermediaries. They know established sectors as well as emerging fields, so they are able to translate between different organizational and epistemic cultures. With the support of border crossers, common places, such as the campus we investigated, open up a space for the exchange of information and interaction between heterogeneous actors.

Policy implications: With more and more countries aiming to increase the share of renewable energies to their national energy supply and the growing diffusion of electric vehicles, the ties between mobility and energy will become even stronger in the future. The foundations of how these ties are going to look are laid out in living labs like the innovation campus we studied. Therefore, it is crucial not only for scholars but also for businesses and policy makers to pay close attention to the developments in these arenas. The living lab of today might become be the new strategic action field of tomorrow - with all kinds of path-dependencies. New challenges for science and innovation policy emerge from these experiences: As has been demonstrated, such living labs are constituted under conditions of severe uncertainty, especially in regards to cooperation models for the sectors involved and their individual ways of thinking, but also in terms of valid scientific evidence and new business models. Thus experimental spaces must be made available in which truly new models of cooperation between heterogeneous actors can be tested. The consequences are not limited to science and innovation policy, which must create a steer- ing model that offers such spaces room between openness and a focus on results. It also concerns the financing formats for statesponsored research and innovation funding that has to take partial failure into account. One could even go so far as to suspend explicit legal framework conditions that play a significant role in the energy and transport transformation, especially, in order to sound out new paths. This would, however, also require radical rethinking within science policy and an overall willingness to bid farewell to supposed guarantees.

\section{List of interviewees}

\begin{tabular}{|c|c|c|c|}
\hline Code & $\begin{array}{l}\text { Description of the } \\
\text { organization }\end{array}$ & $\begin{array}{l}\text { Function of } \\
\text { interviewee }\end{array}$ & Date of interview \\
\hline I1 & $\begin{array}{l}\text { Transdisciplinary hybrid } \\
\text { organization in terms of } \\
\text { sectors, disciplines, early } \\
\text { settler on the campus }\end{array}$ & $\begin{array}{l}\text { Employee in } \\
\text { management } \\
\text { position }\end{array}$ & $04 / 2014$ \\
\hline $\mathrm{I} 2$ & $\begin{array}{l}\text { Joint venture by companies } \\
\text { from the energy, } \\
\text { technology and automotive } \\
\text { sector, located on the } \\
\text { campus }\end{array}$ & CEO & $05 / 2015$ \\
\hline I3 & $\begin{array}{l}\text { Global player in energy } \\
\text { management, office on the } \\
\text { campus }\end{array}$ & $\begin{array}{l}\text { Employee in } \\
\text { management } \\
\text { position }\end{array}$ & $09 / 2013$ \\
\hline $\mathrm{I} 4$ & $\begin{array}{l}\text { Start-up in the area of } \\
\text { charging infrastructure, } \\
\text { located on the campus }\end{array}$ & CEO & $08 / 2014$ \\
\hline I5 & $\begin{array}{l}\text { Large mobility and logistics } \\
\text { provider, office on the } \\
\text { campus }\end{array}$ & $\begin{array}{l}\text { Employee in } \\
\text { management } \\
\text { position }\end{array}$ & $09 / 2013$ \\
\hline I6 & $\begin{array}{l}\text { Power company, } \\
\text { participant in technology } \\
\text { development projects on } \\
\text { the campus }\end{array}$ & Program manager & $01 / 2015$ \\
\hline I7 & $\begin{array}{l}\text { Grid company, offices on } \\
\text { the campus }\end{array}$ & Project engineer & $03 / 2014$ \\
\hline I8 & $\begin{array}{l}\text { Global player in ICT, } \\
\text { located on the campus }\end{array}$ & Managing director & $04 / 2015$ \\
\hline I9 & $\begin{array}{l}\text { Local city cleaning } \\
\text { company }\end{array}$ & $\begin{array}{l}\text { Employee in } \\
\text { management } \\
\text { position }\end{array}$ & 09/2013 \\
\hline
\end{tabular}

\section{Acknowledgements}

The research project "D3 Micro Smart Grid EUREF” was part of the promotional program called "International Showcase of Electric Mobility (Berlin-Brandenburg)" that was funded from 2013 to 2016 by the German federal government as well as by the federal states of Berlin and Brandenburg. It was part of the federal government's showcase initiative. The objective of these largescale regional demonstration and pilot projects was to test and promote electric mobility at the interface of energy systems, vehicles and traffic systems. The particular projects' objective was the development and testing of a micro smart grid (MSG) on a designated local site. The accompanying social scientific research in this project was conducted by Franziska Engels, Anna Verena Münch and Dagmar Simon from TU-Campus EUREF gGmbH, an institute at the Technical University Berlin (Source: http://www.emo-berlin. de/en/showcase/overview/).

The research project "Research Campus Mobility2Grid - Renewable Energy and Electromobility for Smart Urban Environments" is part of the funding initiative "Research Campus - public-private partnerships for innovations" of the German Federal Ministry of Education and Research. The main objective of this project group is to assess and implement innovative solutions to ensure an affordable and secure supply of electricity, heat and transport fully based 
on renewable energies. The project is divided into a preliminary phase lasting from March 2013 until March 2015 and a main phase that started in January 2016 and is expected to last until 2020. The interviews were conducted as part of the preliminary phase by Christoph Biester, Tim Flink, and Jan-Christoph Rogge.

\section{References}

[1] Esteve Almirall, Jonathan Wareham, Living labs: arbiters of mid- and ground-level innovation, Technol. Anal. Strateg. Manag. 23 (1) (2011) 87-102, http://dx.doi.org/10.1080/09537325.2011.537110.

[2] Birgitta B. Kareborn, Anna Stahlbrost, Living lab: an open and citizen-centric approach for innovation, Int. J. Innov. Reg. Dev. 1 (4) (2009) 356, http://dx.doi. org/10.1504/IJIRD.2009.022727.

[3] Regenerative Sustainable Development of Universities and Cities: The Role of Living Laboratories, in: Ariane König (Ed.), Edward Elgar Publishing, Northampton, MA, 2013.

[4] James Evans, Andrew Karvonen, Give me a laboratory and i will lower your carbon footprint!: urban laboratories and the governance of low-carbon futures, Int. J. Urban Reg. Res. 38 (2) (2014) 413-430, http://dx.doi.org/10. 1111/1468-2427.12077.

[5] James Evans, Andrew Karvonen, Rob Raven, The Experimental City: new modes and prospects of urban transformation, in: James Philip Martin Evans, Andrew Karvonen, Rob Raven (Eds.), Routledge Research in Sustainable Urbanism, The Experimental City, Routledge Taylor \& Francis Group, London, New York, 2016, pp. 1-12.

[6] Walter W. Powell, Douglas R. White, Kenneth W. Koput, Jason Owen-Smith, Network dynamics and field evolution: the growth of interorganizational collaboration in the life sciences, Am. J. Sociol. 110 (4) (2005) 1132-1205, http://dx.doi.org/10.1086/421508.

[7] Walter W. Powell, Kenneth W. Koput, Laurel Smith-Doerr, Interorganizational collaboration and the locus of innovation: networks of learning in biotechnology, Adm. Sci. Q. 41 (1) (1996) 116-145, http://dx.doi.org/10.2307/ 2393988.

[8] European Commission, Energy Roadmap 2050, European Commission, Brussels, 2011 (Retrieved September 3, 2015) https://www.kowi.de/ Portaldata/2/Resources/fp7/coop/com-2011-Energy-Roadmap-2050-en.pdf.

[9] IEA, World Energy Outlook 2012, 2012.

[10] IEA, Global EV Outlook 2016, International Energy Agency, 2016.

[11] IPCC, Climate Change 2014: Synthesis Report, Intergovernmental Panel on Climate Change, Geneva, 2015.

[12] Frank W. Geels, Transformations of large technical systems: a multilevel analysis of the Dutch highway system (1950-2000), Sci. Technol. Hum. Values 32 (2) (2007) 123-149, http://dx.doi.org/10.1177/0162243906293883.

[13] Harald Rohracher, Energy systems in transition: contributions from social sciences, Int. J. Environ. Technol. Manag. 9 (2/3) (2008) 144, http://dx.doi.org/ 10.1504/IJETM.2008.019026.

[14] Bernhard Truffer, Jan-Peter Voß, Kornelia Konrad, Mapping expectations for system transformations: lessons from sustainability foresight in German utility sectors, Technol. Forecasting Soc. Change 75 (9) (2008) 1360-1372. http://dx.doi.org/10.1016/j.techfore.2008.04.001.

[15] Alexander Wentland, An automobile nation at the crossroads: reimagining Germany's car society through the electrification of transportation, in: G. Verschraegen, F. Vandermoere, L. Braeckmans, B. Segaert (Eds.), Routledge Studies in Science, Technology and Society, Vol. 34, Imagined Futures in Science, Technology and Society, Routledge, Abingdon Oxon, New York, 2017, pp. 137-165

[16] Christian von Hirschhausen, The German "Energiewende": an introduction, Econ. Energy Environ. Policy 3 (2) (2014) s1, http://dx.doi.org/10.5547/2160 5890.3.2.chir

[17] Dörte Ohlhorst, Germany's energy transition policy between national targets and decentralized responsibilities, J. Integr. Environ. Sci. 12 (4) (2015) 303-322, http://dx.doi.org/10.1080/1943815X.2015.1125373.

[18] Karsten Kieckhäfer, Katharina Wachter, Thomas S. Spengler, Analyzing manufacturers' impact on green products' market diffusion-the case of electric vehicles, J. Clean. Prod. (2016), http://dx.doi.org/10.1016/j.jclepro. 2016.05.021.

[19] Eric Borden, Stonington Joel, Germany's Energiewende, in: Woodrow W. Clark (Ed.), Global Sustainable Communities Handbook. Green Design Technologies and Economics, Butterworth-Heinemann, Amsterdam, Boston, 2014, pp. 369-386.

[20] René Kemp, Arie Rip, Johan Schot, Constructing transition paths through the management of niches, in: R. Garud, P. Karnøe, N.J. Mahwah (Eds.), LEA's Organization and Management Series, Path Dependence and Creation, Lawrence Erlbaum Associates, 2001, pp. 269-299 http://doc.utwente.nl/ 42568/.

[21] Neil Fligstein, Doug McAdam, Toward a general theory of strategic action fields, Sociol. Theory 29 (1) (2011) 1-26, http://dx.doi.org/10.1111/j.14679558.2010.01385.x.

[22] Neil Fligstein, Doug McAdam, A Theory of Fields, Oxford University Press, New York, 2012.

[23] Sjoerd Bakker, Harro van Lente, Remko Engels, Competition in a Technological Niche: The Cars of the Future (5, No. Text), 2012
[24] Marc Dijk, A socio-technical perspective on the electrification of the automobile: niche and regime interaction, Int. J. Automot. Technol. Manag. 14 (2) (2014) 158-171.

[25] Frank W. Geels, Johan Schot, Typology of sociotechnical transition pathways, Res. Policy 36 (3) (2007) 399-417, http://dx.doi.org/10.1016/j.respol.2007.01. 003.

[26] Frank W. Geels, From sectoral systems of innovation to socio-technical systems, Res. Policy 33 (6-7) (2004) 897-920, http://dx.doi.org/10.1016/j. respol.2004.01.015.

[27] René Kemp, Johan Schot, Remco Hoogma, Regime shifts to sustainability through processes of niche formation: the approach of strategic niche management, Technol. Anal. Strateg. Manag. 10 (2) (1998) 175-198, http://dx. doi.org/10.1080/09537329808524310.

[28] Arie Rip, René Kemp, Technological change, in: Steve Rayner, Elisabeth Malone (Eds.), Human Choice and Climate Change. Vol. II, Resources and Technology, Battelle Press, 1998, pp. 327-399.

[29] Frank W. Geels, Technological transitions as evolutionary reconfiguration processes: a multi-level perspective and a case-study, Res. Policy 31 (8-9) (2002) 1257-1274, http://dx.doi.org/10.1016/S0048-7333(02)00062-8.

[30] Kornelia Konrad, Bernhard Truffer, Jan-Peter Voß, Multi-regime dynamics in the analysis of sectoral transformation potentials: evidence from German utility sectors, J. Clean. Prod. 16 (11) (2008) 1190-1202, http://dx.doi.org/10. 1016/j.jclepro.2007.08.014.

[31] Rob Raven, Geert Verbong, Multi-regime interactions in the Dutch energy sector: the case of combined heat and power technologies in the Netherlands 1970-2000, Technol. Anal. Strateg. Manag. 19 (4) (2007) 491-507, http://dx. doi.org/10.1080/09537320701403441.

[32] Eva Schmid, Brigitte Knopf, Anna Pechan, Putting an energy system transformation into practice: the case of the German Energiewende, Energy Res. Soc. Sci. 11 (2016) 263-275, http://dx.doi.org/10.1016/j.erss.2015.11.002.

[33] Frank W. Geels, Ontologies, socio-technical transitions (to sustainability), and the multi-level perspective, Res. Policy 39 (4) (2010) 495-510, http://dx.doi. org/10.1016/j.respol.2010.01.022.

[34] Frank W. Geels, The multi-level perspective on sustainability transitions: responses to seven criticisms, Environ. Innov. Societal Transitions 1 (1) (2011) 24-40, http://dx.doi.org/10.1016/j.eist.2011.02.002.

[35] David Tyfield, Putting the power in 'socio-technical regimes': E-mobility transition in China as political process, Mobilities 9 (4) (2014) 585-603, http://dx.doi.org/10.1080/17450101.2014.961262.

[36] Frank W. Geels, Wim A. Smit, Failed technology futures: pitfalls and lessons from a historical survey, Futures 32 (9-10) (2000) 867-885, http://dx.doi.org/ 10.1016/S0016-3287(00)00036-7.

[37] Paul J. DiMaggio, Walter W. Powell, The iron cage revisited: institutional isomorphism and collective rationality in organizational fields, Am. Sociol. Rev. 48 (2) (1983) 147-160, http://dx.doi.org/10.2307/2095101.

[38] Walter W. Powell, Paul DiMaggio, The New Institutionalism in Organizational Analysis, University of Chicago Press, Chicago, 1991.

[39] W. Richard Scott, Reflections on a half-century of organizational sociology, Annu. Rev. Sociol. 30 (2004) (2004) 1-21.

[40] Richard Scott, Institutional Environments and Organizations: Structural Complexity and Individualism, SAGE Publications, Thousand Oaks, 1994.

[41] Thomas B. Lawrence, Institutional strategy, J. Manag. 25 (2) (1999) 161-187.

[42] M.T. Dacin, Jerry Goodstein, W.R. Scott, Institutional theory and institutional change: introduction to the special research forum, Acad. Manag. J. 45 (1) (2002) 45-56, http://dx.doi.org/10.5465/AMJ.2002.6283388.

[43] C.R. Hinings, Royston Greenwood, Trish Reay, Roy Suddaby, Dynamics of change in organizational fields, in: M.S. Poole, Van de Ven, H. Andrew (Eds.), Handbook of Organizational Change and Innovation, Oxford University Press, Oxford, UK, New York, N.Y, 2004, pp. 304-323.

[44] Alan D. Meyer, Vibha Gaba, Kenneth A. Colwell, Organizing far from equilibrium: nonlinear change in organizational fields, Organ. Sci. 16 (5) (2005) 456-473, http://dx.doi.org/10.1287/orsc.1050.0135.

[45] Andrew J. Hoffman, Institutional evolution and change: environmentalism and the US chemical industry, Acad. Manag. J. 42 (4) (1999) 351-371, http:/ dx.doi.org/10.2307/257008.

[46] Silvia Dorado, Institutional entrepreneurship, partaking, and convening, Organ. Stud. 26 (3) (2005) 385-414, http://dx.doi.org/10.1177/ 0170840605050873.

[47] Paul-Brian McInerney, Showdown at Kykuit: field-configuring events as loci for conventionalizing accounts, J. Manag. Stud. 45 (6) (2008) 1089-1116.

[48] Matthias Gross, Holger Hoffmann-Riem, Wolfgang Krohn, Realexperimente: Ökologische Gestaltungsprozesse in der Wissensgesellschaft, transcript-Verl., Bielefeld, 2005.

[49] Matthias Gross, Give me an experiment and I will raise a laboratory, Sci. Technol. Hum. Values 41 (4) (2016) 613-634, http://dx.doi.org/10.1177/ 0162243915617005.

[50] Halina S. Brown, Philip J. Vergragt, Ken Green, Luca Berchicci, Bounded sociotechnical experiments (BSTEs): higher order learning for transitions towards sustainable mobility, in: Boelie Elzen, Frank W. Geels, Ken Green (Eds.), System Innovation and the Transition to Sustainability: Theory, Evidence and Policy, Edward Elgar Publishing, Cheltenham, UK, Northampton, MA, 2004, pp. 191-222.

[51] Ulrike Felt, Judith Igelsböck, Andrea Schikowitz, Thomas Völker, Transdisciplinary sustainability research in practice: between imaginaries of collective experimentation and entrenched academic value orders, Sci. 
Technol. Hum. Values 41 (4) (2016) 732-761, http://dx.doi.org/10.1177/ 0162243915626989.

[52] Frank W. Geels, Rob Raven, Non-linearity and expectations in niche-development trajectories: ups and downs in Dutch biogas development (1973-2003), Technol. Anal. Strateg. Manag. 18 (3-4) (2006) 375-392, http:// dx.doi.org/10.1080/09537320600777143.

[53] Ariane König, James Evans, Introduction: experimenting for sustainable development?: living laboratories, social learning and the role of the university, in: A. König (Ed.), Regenerative Sustainable Development of Universities and Cities: The Role of Living Laboratories, Edward Elgar Publishing, Northampton, MA, 2013, pp. 1-23.

[54] Thomas F. Gieryn, Three truth-spots, J. Hist. Behav. Sci. 38 (2) (2002) 113-132 http://dx.doi.org/10.1002/jhbs.10036.

[55] Walter W. Powell, Kenneth W. Koput, James I. Bowie, Laurel Smith-Doerr, The spatial clustering of science and capital: accounting for Biotech Firm-Venture Capital relationships, Reg. Stud. 36 (3) (2002) 291-305, http://dx.doi.org/10. 1080/00343400220122089.

[56] Kjersten B. Whittington, Jason Owen-Smith, Walter W. Powell, Networks, propinquity, and innovation in knowledge-intensive industries, Adm. Sci. Q. 54 (1) (2009) 90-122, http://dx.doi.org/10.2189/asqu.2009.54.1.90.

[57] Joseph Lampel, Alan D. Meyer, Field-configuring events as structuring mechanisms: how conferences, ceremonies, and trade shows constitute new technologies, industries, and markets, J. Manag. Stud. 45 (6) (2008).

[58] Raghu Garud, Conferences as venues for the configuration of emerging organizational fields: the case of cochlear implants, J. Manag. Stud. 45 (6) (2008) 1061-1088, http://dx.doi.org/10.1111/j.1467-6486.2008.00783.x.

[59] Claire B. Draucker, Donna S. Martsolf, Ratchneewan Ross, Thomas B. Rusk, Theoretical sampling and category development in grounded theory, Qual. Health Res. 17 (8) (2007) 1137-1148, http://dx.doi.org/10.1177/ 1049732307308450.

[60] Dennis A. Gioia, Kevin G. Corley, Aimee L. Hamilton, Seeking qualitative rigor in inductive research: notes on the Gioia methodology, Organ. Res. Methods 16 (1) (2013) 15-31, http://dx.doi.org/10.1177/1094428112452151.

[61] Bruce L. Berg, Howard Lune, Qualitative Research Methods for the Social Sciences, 8th ed., Pearson, Boston, 2012.

[62] Andreas Witzel, The problem-centered interview, Forum Qualitative Sozialforschung/Forum Qual. Soc. Res. 1 (1) (2000).

[63] Juliet M. Corbin, Anselm L. Strauss, Basics of Qualitative Research: Techniques and Procedures for Developing Grounded Theory, 3rd ed., Sage Publications Inc., Los Angeles Calif, 2008.

[64] Barney G. Glaser, Anselm L. Strauss, The Discovery of Grounded Theory: Strategies for Qualitative Research, Aldine de Gruyter, New York, 1967.

[65] Johnny Saldaña, The Coding Manual for Qualitative Researchers, Sage, Los Angeles, Calif, 2009

[66] Franziska Engels, Anna V. Münch, The micro smart grid as a materialised imaginary within the German energy transition: special issue on smart grids and the social sciences, Energy Res. Soc. Sci. 9 (2015) 35-42, http://dx.doi.org 10.1016/j.erss.2015.08.024.

[67] Franziska Engels, Anna V. Münch, Dagmar Simon, One site-multiple visions: visioneering between contrasting actor's perspectives, Nanoethics 11 (1) (2017), http://dx.doi.org/10.1007/s11569-017-0290-9.

[68] Mads Borup, Nik Brown, Kornelia Konrad, Harro van Lente, The sociology of expectations in science and technology, Technol. Anal. Strateg. Manag. 18 (3-4) (2006) 285-298, http://dx.doi.org/10.1080/09537320600777002.

[69] IEA, World Energy Outlook 2012, 2012.
[70] Rodica Loisel, Guzay Pasaoglu, Christian Thiel, Large-scale deployment of electric vehicles in Germany by 2030: an analysis of grid-to-vehicle and vehicle-to-grid concepts, Energy Policy 65 (2014) 432-443, http://dx.doi.org/ 10.1016/j.enpol.2013.10.029.

[71] Alexander Wentland, Imagining and enacting the future of the German energy transition: electric vehicles as grid infrastructure, Innovation Eur. J Soc. Sci. Res. 29 (3) (2016) 285-302, http://dx.doi.org/10.1080/13511610. 2016.1159946

[72] NPE, Fortschrittsbericht 2014: Bilanz der Marktvorbereitung, Nationale Plattform Elektromobilität, Berlin, 2014 https://www.bmbf.de/files/NPE_ Fortschrittsbericht_2014_barrierefrei.pdf.

[73] Willett Kempton, Jasna Tomić, Vehicle-to-grid power implementation: from stabilizing the grid to supporting large-scale renewable energy, J. Power Sources 144 (1) (2005) 280-294, http://dx.doi.org/10.1016/j.jpowsour.2004. 12.022 .

[74] Johannes Liebl, Grid Integration of Electric Mobility, Springer Fachmedien Wiesbaden, Wiesbaden, 2017.

[75] Bundesnetzagentur, “Smart Grid” und “Smart Market”: Eckpunkte-Papier der Bundesnetzagentur zu den Aspekten des sich verändernden Energieversorgungssystems, Bundesnetzagentur, Bonn, 2011 http://www bundesnetzagentur.de/SharedDocs/Downloads/DE/Sachgebiete/Energie/ Unternehmen_Institutionen/NetzzugangUndMesswesen/ SmartGridEckpunktepapier/SmartGridPapierpdf.pdf?_blob=publicationFile\&v $=$.

[76] Fabian Reetz, Multidimensionale Vernetzung: Lösungen für urbane Fragestellungen, Polis - Magazin für Urban Development 4 (2012) 80-81 (Retrieved May 13, 2016) http://www.bemobility.de/file/bemobility-de/ 2568154/8BYWWZPdcsMrQ_rTsWicX-Wxl7M/3197202/data/reetz_polis_0412.pdf.

[77] Ulrike Felt, The temporal choreographies of participation: thinking innovation and society from a temporal perspective, in: J. Chilvers, M. Kearnes (Eds.), Remaking Participation: Science, Environment and Emergent Publics, Routledge, London, New York, 2016, pp. 178-198, Routledge is an imprint of the Taylor \& Francis Group.

[78] Thomas F. Gieryn, Boundary-work and the demarcation of science from non-science. Strains and interests in professional ideologies of scientists, Am. Sociol. Rev. 48 (6) (1983) 781-795 http://www.jstor.org/stable/2095325.

[79] David H. Guston, Stabilizing the boundary between US politics and science: the role of the office of technology transfer as a boundary organization, Soc. Stud. Sci. 29 (1) (1999) 87-111.

[80] Neil Fligstein, Social skill and the theory of fields, Sociol. Theory 19 (2) (2001) 105-125, http://dx.doi.org/10.1111/0735-2751.00132.

[81] Craig Morris, Germany's Energiewende. Community-Driven Since the 1970s, in: W.W. Clark (Ed.), Global Sustainable Communities Handbook: Green Design Technologies and Economics, Butterworth-Heinemann, Amsterdam, Boston, 2014

[82] Ulrich Dolata, Soziotechnischer Wandel als graduelle Transformation, Berliner Journal für Soziologie 21 (2) (2011) 265-294, http://dx.doi.org/10. 1007/s11609-011-0153-0.

[83] Weert Canzler, Andreas Knie, Die digitale Mobilitätsrevolution: Vom Ende des Verkehrs wie wir ihn kannten, oekom verlag, München, 2016.

[84] Thomas Blanchet, Struggle over energy transition in Berlin: how do grassroots initiatives affect local energy policy-making? Energy Policy 78 (2015) 246-254, http://dx.doi.org/10.1016/j.enpol.2014.11.001. 